\title{
The Role of Organizational Culture in Intellectual Capital: A Case Study of Salahuddin University-Erbil
}

\author{
Galaweezh Jameel Abbas \\ Independent Researcher, Kurdistan Region of Iraq \\ E-mail: galawezhjamel@gmail.com
}

Received: October 24, 2019 Accepted: November 28, 2019 Published: December 15, 2019

doi:10.5296/wjbm.v5i2.15700

URL: https://doi.org/10.5296/wjbm.v5i2.15700

\begin{abstract}
This paper's purpose is to examine the role of organizational culture on intellectual capital as a case study conducted at Salahaddin University colleges in Erbil. That represented in all 14 colleges in Erbil, then distributing (88) questionnaire forms on the respondents, (82) valid form were obtained for analysis. So, the method adopted by the research is to identify the research problem by asking several questions centered on the nature of the relationship and effect between the research variables. Although a conceptual scheme designed to establish and test the research hypotheses through a range of statistical tests. However, a descriptive analytical method was used to reach the research results. Hence, Spearman correlation and multiple regression analysis respectively applied in order to determine the degree of the relationship and prediction of intellectual capital. As a result, this paper reached some conclusions, most notably presence the importance of the organizational culture and intellectual capital components. Moreover, the results showed that the organizational culture and it is components have an essential relationship in forming intellectual capital. Besides, the study found the organizational culture effect on intellectual capital.
\end{abstract}

Keywords: Organizational Culture, Intellectual Capital, and Academic Institution 


\section{Introduction}

This research paper examines the effect and correlation between the organizational culture and intellectual capital to allow the proposal of a model to measure organizational culture and intellectual capital in Salahaddin university colleges. The importance of organizational culture and its impact on intellectual capital is now prevalent in practice in developed countries, and there is sufficient understanding among administrators of how to change the culture that has prevented the institution from being productive. While, academic institutions are the organizational unit composed of several sub-systems, namely the academic system and the system it affects and is affected by these subsystems as a transparent border format on the society and the environment in which it is acting as the primary source of its inputs besides works hard to direct its outputs. So, the topic of organizational culture has received considerable attention from economic theorists, thinkers, sociologists, and others; then they tried to address some of the issues and problems they are experiencing in parallel with academic developments witnessed by a highly competitive and rapidly changing professional environment. Accordingly, this model highlights culture as a critical element of intellectual capital. First, the concept of culture is defined. Then we observe separately the main models that are used to test intellectual capital, concentrating on their structure and the location of culture. Following, the significance of this capital for establishments. Lastly, the proposed model is elicited, and the established relationships between all the components of intellectual capital are explained, using culture as the central nucleus.

\subsection{Reasons for Choosing a Topic}

The choice of the topic back to the role of the organizational culture in controlling the staffs' behavior within the organization, which motivated by the personal inclination of this type of study and its integration within the discipline of organization and it is effort. Organizational culture has become one of the topics of great interest in the institution and organizational behavior areas, considering that culture is one of the main determinants of the success and failure of the organization. Further, deficiency of attention to the human and cultural aspect of the institutions in the Kurdistan Region, for human resources, which is working to implement plans and policies of work.

\subsection{Problem Statement}

The public institutions suffer expressively from difficulties as a result of long periods under the extreme umbrella of centralization, mainly in Iraq and the Kurdistan region that Salahaddin University-Erbil one of them. Accordingly, the hierarchical management levels, and the involvedness of the official lines of communication, as well as the discretion of information given to academic staffs these formed an obstacle to the institutional development and reform ambitions of organizations. While organizational culture is one of the factors that motivate and encourage staff, to employ their abilities and creative skills, for the better, by producing a cohesive culture characterized, by the spirit of participation of all members of the institution whom they share a homogeneous set of values, beliefs, traditions, and norms that govern their behavior within an organization, however, the institution's broad values and beliefs, adhered firmly by everyone increases the loyalty of staffs and their loyalty 
to the organization. Organizational culture also represents a significant competitive advantage for the organization with positive results, especially strong ones, in formulating to guide human behavior, hence this paper attempt to identify the impact of organization culture on institutions' intellectual capital.

\subsection{Research Purposes}

The primary purpose of this research paper is to examine the role of organizational culture on intellectual capital as a case study conducted at Salahaddin University colleges in Erbil, which includes the following comprehensive purposes:

1) Simplify the thoughts of organizational culture and intellectual capital at Salahaddin University colleges in Erbil.

2) Attempting to know whether the colleges of Salahaddin university have a supportive organizational culture that modifies and estimates the behavior of staff, expressing their performance.

3) Reveal the reality of the cultural values and norms, the culture of teamwork, the culture of participation, and culture of consistency within the colleges of Salahaddin university.

4) Identify methods and different ways that could use to make university colleges and their science departments more developed.

5) Describe the relationship effect of organizational culture and intellectual capital.

\subsection{The Study Significance}

The significance of the study stems from the fact that organizational culture and intellectual capital are the sources of the institution's challenge, success, and failure. Thus, the desire to know the role of the organizational culture in controlling the behavior of the employee within the organization by practicing the institution's intellectual capital is vital. Hence this study also significance while interpret intellectual capital models in light of the prevailing organizational culture in the public institution (Salahaddin University). However, the consequence of this subject lies in the fact that it is mainly linked at the same time to two elements. The first is intellectual capital as the human element, which is the main focus at all levels of the organization. The second element is the institution itself. Where organizational culture is one of the priorities of institutional planning and change to try to realize and predict it in the future.

\subsection{Research Questions}

In accord with the research problem and its purpose, this paper emphases the significant features by asking, then answer the main research question: To what extent organizational culture effect intellectual capital? Accordingly, to answer this question, this research addresses the following sub-questions:

1) Is there a supportive organizational culture in the Salahaddin University colleges in Erbil, and what are the levels? 
2) What is the nature of the organizational culture relationship with Salahaddin university's intellectual capital?

3) How does organizational culture components affecting to practice the intellectual capital in the Salahaddin University colleges in Erbil?

\subsection{Conceptual Scheme}

The conceptual scheme is based on the literature related to the research topic. Thus, bearing inattention of the research purpose to examine the role of organizational culture on intellectual capital as a case study conducted at Salahaddin University colleges in Erbil, that issues a conceptualization of the exclusive concepts related to the topic of the research also the relationship and effects among them, as revealed in Figure 1, below.

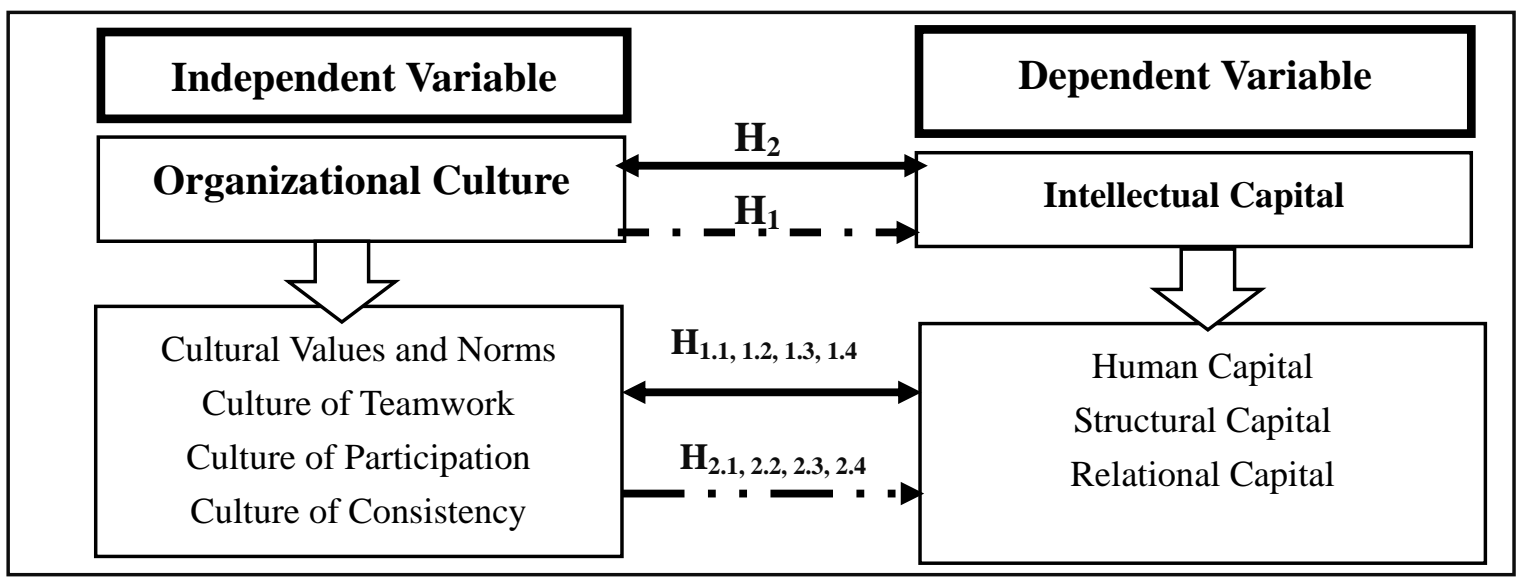

Figure 1: The Research's Conceptual Scheme - Developed by Researcher Based on Literature

\subsection{Hypotheses}

Hypothetically, this research conduct on the undertaking organizational culture as cultural values and norms, culture of teamwork, culture of participation, and culture of consistency), have relationship effect in the intellectual capital of the of Salahaddin University-Erbil. Therefore, the research paper pursues to test the following hypotheses:

Hypothesis $H_{1}$ : Organizational culture has a positive relationship with intellectual capital at the level of $(0 \leq 0.05)$.

$H_{1.1}$ : Cultural values and norms have a positive relationship with intellectual capital.

$H_{1.2}$ : Culture of teamwork has a positive relationship with intellectual capital.

$H_{1.3:}$ Culture of participation has a positive relationship with intellectual capital.

$H_{1.4:}$ Culture of consistency has a positive relationship with intellectual capital.

Hypothesis $\mathrm{H}_{2}$ : There is a positive effect of the organizational culture in the intellectual 
capital at the level of $(0 \leq 0.05)$.

$H_{2.1}$ : Cultural values and norms affect in intellectual capital.

$H_{2.2}$ : Culture of teamwork effect in intellectual capital.

$H_{2.3}$ : Culture of participation effect in intellectual capital.

$H_{2.4}$ : Culture of consistency effect in intellectual capital.

\section{Literature Review}

\subsection{The Concept of Organizational Culture}

Organizational culture is a set of values, norms, and codes of conduct shared by the individual and groups in the organization that governs the way they interact with each other and with other stakeholders (Stephen \& Stephen, 2016, p. 37). The values of the organization constitute the beliefs and ideas associated with the types of goals to be adopted by the members of the organization and standards (Tarvonen, 2018, p. 67). Behaviors that members of the organization must have to achieve those goals (Zafar et al., 2016, p. 51). It recognizes that 'the set of human values and concepts that are created, developed within the working groups in the organization, and educate staff to determine the way they think, perceive, feel towards the internal and external work environment besides determining their behavior, affect their performance and productivity. This definition indicates that organizational culture is the values that arise in an organization that characterizes the behavior of employees and affects their performance. Accordingly, organizational culture is one of the self-reinforcing methods of each organization. With a widespread and robust culture, stability is achieved, the staff knows what is expected of them, what is most important, and what is being done (Zafar, 2016, p. 42).

\subsection{The Components of Organizational Culture}

According to Parnell and Crandall (2001, p. 527), organizational culture has a set of components that differentiate it from other sorts of cultures of organizations. While various components that demonstrate the supportive organizational culture in four essential components, namely cultural values and norms, the culture of teamwork, culture of participation, and culture of consistency. In this regard, some values, norms, rules enable staff to decide between error, right, desirable and unwanted what should be a guide and monitor of human behavior as it provides staffs with a view of individual trends and the nature of organizational culture (Khamis, 2012, p. 203). The significant of these values and norms is the occurrence of staff and their departure from the organization at times of organizational regulation, equality of staff, care to academic performance, and respect for others (Cheung, 2011, p. 36). The culture of teamwork highlights a flexible institution's internal trends, concentrating mainly on the sharing of information, trust, authorization, and teamwork. So, the institution, which stresses teamwork, wants to reach a society that is approachable and trusts each other like a family (Sánchez-Canizares et al., 2007, p. 409). Culture of participation conditions to improved participation of administrators and staff in decision making since they have faith in this will progress the efficiency of the organization and does 
not outcome in a decrease in organizational strength (Parnell \& Crandall, 2001, p. 529). Systems that offer prospects for staff engagement, or a sense of developing an organization's culture, are stimulated to indulge in work (Schreiner, 2005, p. 1396). Besides enhancing the sense of responsibility towards the outcome of the business and increases the individual commitment to the psychological aspect of organizations that create the principle of participation works to raise morale and motivate staffs to perform their jobs, and thus shape their responsibility towards the work (Shooshtri, 2016: 32). Culture of consistency emphasis on organizational trends, which focus on laws, principles, and productivity (Elias, 2006, p. 25) as well as the connection among the staffs of the organization and the extent of these relations, and the importance of these relations in achieving cohesion among staffs (Schein, 2010).

\subsection{The Concept of Intellectual Capital}

Intellectual capital is one of the intangible assets to which contemporary organizations have given great importance (Corcoles, 2012, p. 5). It is the primary driver of creativity and innovation besides is one of the priorities for achieving excellence and continuity (Wali, 2007, p. 76). Intellectual capital is also defined as those intellectual assets whose value exceeds the value of other assets that appear in the balance sheet (Corcoles, 2012). However, Daft (2010, p. 257) refers to intellectual capital as a set of information resources in the form of two types of knowledge, visible knowledge that can be easily expressed or written, and thus transmitted to others in the form of documents. As indicated by Fernstrom et al. (2005, p. 492) tacit knowledge based on personal experience and self-evident rules, that is used in the development of the organization. Chatzkel, (2002, p. 7) emphasizes that the concept of intellectual capital from an administrative point of view is the knowledge that can be converted into value or profit, that is, the value embedded in the ideas inherent in individuals, processes, customers, and stakeholders. Mirkhan (2002, p. 25) also describes intellectual capital as the intangible real wealth that cannot be valued. Since it is a potential mental capacity possessed by some human capital staffs and its most powerful competitive weapon, as it is the primary source from which all the knowledge and creativity with which the organization can cope with all changes in a complex environment. (Ghasemi \& Naslmosavi, 2011, p. 430), in their definition of intellectual capital, focused on the competitive situation, defining intellectual capital as a set of knowledge assets, affecting the competitive position of the organization. As (Khan et al., 2012, p. 22) refers to intellectual capital, it includes all the resources of an organization that is increasing its value by increasing the efficiency and merit of its intellectual assets.

\subsection{The Importance of Intellectual Capital}

According to Mustafa, (2016, p. 6), intellectual capital is an important variable that has a significant impact on the superiority or failure of the business organization, mainly as this reflects on the market value of the organization. So, intellectual capital represents competitive assets capable of maintaining a level of knowledge within the organization. In this context, Drucker $(1999$, p. 75$)$ points out that the most valuable asset of the 21 st century is intellectual capital as the real power. For the survival and continuity of organizations in light of global challenges and developments. As mentioned by Fernstrom and Roos (2005, p. 490), 
intellectual capital represents a sustainable competitive advantage through organizations working to achieve a competitive edge. In this regard, Farhaf and Abadi (2006, p. 23), pointed to the importance of intellectual capital as follows:

- Intellectual capital is the principal weapon of the organization in today's world as intellectual assets are the dominant force that ensures the survival of the organization.

- Its presence in the organization is a competitive advantage, as a result of these heads providing useful knowledge and increasing the organization's ability to invest that knowledge to achieve competitive advantage.

- The knowledge provided in intellectual capital is unique, unattainable to all, besides makes intellectual contributions that enable the organization to increase its output compared to its counterparts.

- Intellectual capital is an essential source of information advantage, and then intellectual capital is therefore responsible for transforming a resource and distinct knowledge into an economically valuable market.

\subsection{The Components of Intellectual Capital}

The human component is the most critical component of intellectual capital, human beings are a highly complex element because the knowledge and experience can be implicit to them, Stewart defined human capital as a source of innovation and invention because of his mental ability, skills, and experience, to provide practical solutions suitable for customers (Stewart, 1999, p. 76). While Phatak, (2003, p. 6), described human capital as the element that connects all the knowledge, potential, core capabilities, expertise, and creativity of the members of the organization. Human capital in organizations is represented by knowledgeable, skilled, and experienced staff that give the organization its advantage (Dsvsnter, 2000, p. 4). The researcher believes that human capital is represented by the abilities and capabilities of individuals working knowledge, skills and experience, and the ability to learn (individual, collective, and organizational), as well as the ability to creativity and innovation. Stewart $(1999$, p. 75$)$, also defined structural capital as the organizational capacity of an organization that can share, transfers, and enhances knowledge through the structural intellectual assets of information systems, patents, copyrights, and the trademark representing the personality, value, and identity of the organization. Rose (2000, p. 5), argued that the structural capital upon which the organization relies to meet market needs is the knowledge it acquires, which is an integral part of its organizational structure, culture, and operations (Daft, 2010, p. 257). It is believed that the structural capital is an infrastructure owned by the organization, which contributes to support and strengthen all operations, besides consists of systems, policies, information, software, databases, research, and development as well as intellectual property (Chatzkel, 2002, p. 3). According to Nordby (2005, p. 574), relational capital refers to the organization's relations with external parties represented by customers, suppliers, and distributors. Customers' view of the organization and make them feel that they are the primary partner in formulating a long-term strategy, as well as their willingness to abandon this partner (Farhaf \& Abadi, 2006, p. 3). 


\section{Research Method}

The research applied a quantitative method, so, a quantitative method is a suitable approach, as it serves the data collection and analysis, from the academic staff's viewpoint at salahaddin University-Erbil. However, a quantitative method commonly used in the research when deals with statistical data. Therefore, this research formulates correlational and effect research design as it chased to define and find the relations among the main research variables. As a data collection tool, a questionnaire used to measure the organizational capital and intellectual capital. Although a questionnaire supports the method employed in this research, it also, significance for the research design, besides the potential benefits it offers.

\subsection{Sampling}

Initially, the research population comprises the colleges of Salahaddin University - Erbil. So, the colleges selected, as the academic staffs are likely to better recall of organizational culture and institution's intellectual capital, Therefore, (88) academic staffs willingly participated in the survey by replying to the questionnaire items, which self-administered and distributed in the colleges and in particular, thus the reply rate was (93.1) percent. However, six questionnaire forms out the paper questionnaire invalid, excluded from the total survey sample. Hence, the total valid forms were (82), which launches the research sample.

\subsection{Data Analyses}

The parametric and nonparametric statistical tests run to examine the research hypotheses. In this context, the reliability and descriptive analysis applied to define the significant components of the research variables through using Cronbach's alpha for reliability tests, statistical mean, standard deviations, and t-tests. The correlation also used to find the connection between the institution's organizational culture and intellectual capital. Accordingly, multiple linear regression also used to test the hypothesis and to describe the effect of organizational culture in intellectual capital. The SPSS V-25 used for tests and the results presented in tables.

\section{Findings}

\subsection{Demographic Data}

As demonstrated in Table 1, these demographic data collected from Salahaddin University colleges' academic staffs such as; gender, age, academic degree, scientific title, and experience in academic profession, to pursue the survey sample also to attain more information on it and its orientation, thus, the research used descriptive analysis to reach this purpose. 
Table 1. Frequencies and percentages of demographic data

\begin{tabular}{|c|c|c|c|c|}
\hline \multicolumn{3}{|c|}{ Demographic Data } & \multirow{2}{*}{$\frac{\text { Frequency }}{53}$} & \multirow{2}{*}{$\frac{\text { Percent }}{64.6}$} \\
\hline Valid & Gender & Male & & \\
\hline & & Female & 29 & 35.4 \\
\hline & & Total & 82 & 100.0 \\
\hline \multirow[t]{5}{*}{ Valid } & Age & Less than 30 years & 3 & 3.65 \\
\hline & & 30 and less than 40 & 14 & 17.07 \\
\hline & & 40 and less than 50 & 30 & 36.59 \\
\hline & & 50 and above & 35 & 42.68 \\
\hline & & Total & 82 & 100.0 \\
\hline \multirow[t]{3}{*}{ Valid } & Academic & $\mathrm{PhD}$ & 50 & 60.98 \\
\hline & Degree & Master & 32 & 39.02 \\
\hline & & Total & 82 & 100.0 \\
\hline \multirow[t]{5}{*}{ Valid } & Scientific & Professor & 33 & 40.24 \\
\hline & Title & Assist. Professor & 27 & 32.93 \\
\hline & & Lecturer & 10 & 12.20 \\
\hline & & Assist. Lecturer & 12 & 14.63 \\
\hline & & Total & 82 & 100.0 \\
\hline \multirow[t]{5}{*}{ Valid } & Experience in & Less than 10 years & 14 & 17.07 \\
\hline & Academic & 10 and less than 20 & 26 & 31.71 \\
\hline & Profession & 20 and less than 30 & 20 & 24.39 \\
\hline & & 30 and above & 22 & 26.82 \\
\hline & & Total & 82 & 100.0 \\
\hline
\end{tabular}

From the Table below, the male college staffs have constituted $64.6 \%$ or (53) academic staff of the total research sample, comparing to $35.4 \%$ female academic staff or (29) individuals. In the context of age groups Table 1, revealed that $42.68 \%$ of the overall sample respondent or (35) staff aged 50 and above, whereas $36.59 \%$ or (30) respondents aged 40 and less than 50. Also, $17.07 \%$ aged 30 and less than 40 , furthermore $3.65 \%$ or (3) staff who participated in this survey aged less than 30 years. Regarding the survey sample's academic degrees, Table 1 , clarify that $60.98 \%$ or (50) staffs are Ph.D. holders. However, $39.02 \%$ or (32) of the sample are master's degree holders. As demonstrated through Table 1, most of the academic staff who participated in the survey are Professor by $40.24 \%$ or (33), while the least of them is Lecturer, by $12.20 \%$. However, $32.93 \%$ were Assist. Professor, besides $14.63 \%$ of the total sample Assist. Lecturer. Regarding the experience in the academic profession, Table 1 presented that of the total respondents, $31.71 \%$ or (26) staff experienced from 10 years but less than 20 years. Then $26.82 \%$ or (22) academic staffs experienced in the academic profession 30 and above. Besides $24.39 \%$ or (20) of the experienced sample fall in 20 years and less than 30, while the lowest $17.07 \%$ or (14) college staffs of the total survey sample experienced less than 10 years. 


\section{Macrothink}

\subsection{Reliability}

The reliability of internal consistency is a measure of reliability used to assess the degree to which different test elements that explore the same structure lead to similar results. So, the formula for Cronbach's alpha is:

$$
a=\frac{N \cdot \bar{c}}{\bar{v}+(N-1) \cdot \bar{c}}
$$

In regard, survey consistency, Cronbach's alpha used, and the score for total organizational culture indicators is $(0.857>0.60)$ greater than 0.60 . However, the scores of organizational culture components, namely cultural values and norms, teamwork, participation, and culture of consistency are $(0.633,0.635,0.697$, and $0.763>0.60)$, respectively, were all scores greater than 0.60 . The intellectual capital indicators score is $(0.894>0.60)$, and scores of components human, structural, and relational capitals are $(0.829,0.724$, and 0.694>0.60), respectively, also all scores greater than 0.60 . Furthermore, the Cronbach's alpha score for entirely questionnaire indicators is (0.877), which showed a high level of internal consistency for the whole set of indicators of the questionnaire. Subsequently, the questionnaire used to collect could measure highly reliable, as shown in Table 2.

Table 2. Reliability test

\begin{tabular}{lllll}
\hline Variables & Cronbach's Alpha & No. of Items & N & \% \\
\hline Organizational Culture & $\mathbf{0 . 8 5 7}$ & $\mathbf{2 0}$ & $\mathbf{8 2}$ & $\mathbf{1 0 0 . 0}$ \\
Cultural Values and Norms & 0.633 & 5 & 82 & 100.0 \\
Culture of Teamwork & 0.635 & 5 & 82 & 100.0 \\
Culture of Participation & 0.697 & 5 & 82 & 100.0 \\
Culture of Consistency & 0.763 & 5 & 82 & 100.0 \\
Intellectual Capital & $\mathbf{0 . 8 9 4}$ & $\mathbf{1 7}$ & $\mathbf{8 2}$ & $\mathbf{1 0 0 . 0}$ \\
Human Capital & 0.829 & 5 & 82 & 100.0 \\
Structural Capital & 0.724 & 6 & 82 & 100.0 \\
Relational Capital & 0.694 & 6 & 82 & 100.0 \\
Overall & $\mathbf{0 . 8 7 7}$ & $\mathbf{3 7}$ & $\mathbf{8 2}$ & $\mathbf{1 0 0 . 0}$ \\
\hline
\end{tabular}

\subsection{Descriptive Statistics}

This sub-section goal is to launch examine of the sample replies to the questionnaire's indicators, which requested to rate the significance of the components of organizational culture and intellectual capital on the five-point Likert Scale.

$$
\text { Rate of Agreement }=\frac{\text { Mean } * 100}{5(\text { Five Point Likert Scale })}
$$


In this context, the descriptive analysis runs to compute the (statistical mean, deviation scores, t-test, and weight of agreement) of each variable organizational culture, intellectual capital, and their components. Table 3, determine the statistical mean and standard deviation outcomes for the organizational culture as the independent variable (3.3805, and 0.42512), respectively. So, $67.61 \%$ of the total replies agreed that organizational culture significant for improving and effective practices of intellectual capital; that maintained through t-test (72.007) df (81), significant at the level $(0.000<0.05)$. While, the means scores of the organizational culture components as; cultural values and norms, teamwork, participation, and consistency are $(3.4976,3.3073,3.378$, and 3.339), respectively. Besides standard deviations scores are $(0.48508,0.45995,0.59959$, and 0.60262$)$ respectively. It means that $(69.95 \%, 66.15 \%, 67.56 \%$, and $66.78 \%)$ respectively, agreed on the significance of the institution's cultures. Supported by t-test $(65.292,65.114,51.017$, and 50.175$)$ respectively at the p-values $(0.000,0.000,0.000$, and 0.000$)$ respectively, which all less than alpha 0.05 . Hence, it is components significant ( $\mathrm{p}$-value $<0.05$ ).

Table 3. The results of descriptive analysis and T-test

\begin{tabular}{lcccccc}
\hline \multirow{2}{*}{ Variables } & \multicolumn{3}{c}{ Descriptive Statistics } & \multicolumn{3}{c}{ T-test } \\
\cline { 2 - 7 } & Mean & $\begin{array}{c}\text { Std. } \\
\text { Deviation }\end{array}$ & $\begin{array}{c}\text { The rate of } \\
\text { Agreement }\end{array}$ & t & df & $\begin{array}{c}\text { Sig. } \\
\text { (2-tailed) }\end{array}$ \\
\hline Organizational Culture & 3.3805 & 0.42512 & $\mathbf{6 7 . 6 1 \%}$ & 72.007 & 81 & 0.000 \\
Cultural Values and & 3.4976 & 0.48508 & $\mathbf{6 9 . 9 5 \%}$ & 65.292 & 81 & 0.000 \\
Norms & & & & & & \\
Culture of Teamwork & 3.3073 & 0.45995 & $\mathbf{6 6 . 1 5 \%}$ & 65.114 & 81 & 0.000 \\
Culture of Participation & 3.3780 & 0.59959 & $\mathbf{6 7 . 5 6 \%}$ & 51.017 & 81 & 0.000 \\
Culture of Consistency & 3.3390 & 0.60262 & $\mathbf{6 6 . 7 8 \%}$ & 50.175 & 81 & 0.000 \\
Intellectual Capital & 3.6098 & 0.49849 & $\mathbf{7 2 . 2 0 \%}$ & 65.573 & 81 & 0.000 \\
Human Capital & 3.6545 & 0.52755 & $\mathbf{7 3 . 0 9 \%}$ & 62.728 & 81 & 0.000 \\
Structural Capital & 3.4293 & 0.64262 & $\mathbf{6 8 . 5 9 \%}$ & 48.323 & 81 & 0.000 \\
Relational Capital & 3.7154 & 0.50748 & $\mathbf{7 4 . 3 1 \%}$ & 66.298 & 81 & 0.000 \\
\hline
\end{tabular}

Moreover, Table 3 above demonstrated the mean and standard deviation results for the intellectual capital (33.6098, and 0.49849), respectively. Also, 72.20\% of the total sample answers agreed that intellectual capital important for Salahaddin university colleges; its t-test (65.573) $\boldsymbol{d} \boldsymbol{f}(81)$, significant at the level $(0.000<0.05)$. The means scores of the intellectual capital components as; human, structural capital, and relational capitals are (3.6545, 3.4293, and 3.7154), respectively. The standard deviations are $(0.5275,0.6426$, and 0.50748) respectively. It means that $(73.09 \%, 68.59 \%$, and $74.31 \%)$ respectively, agreed on the significance of the institution's intellectual capital. Supported by t-test $(62.728,48.323$, and $66.298)$ respectively at the p-values $(0.000,0.000$, and 0.000$)$ respectively, less than alpha 0.05. The results presented that organizational culture and it is components would effect on intellectual capital. However, the cultural values and norms, the culture of participation, and culture of consistency, respectively, the critical elements that were motivating to the effect on 


\section{Macrothink}

World Journal of Business and Management

ISSN 2377-4622

2019, Vol. 5, No. 2

intellectual capital, but the culture of teamwork have the lowest effect compared to other components.

\subsection{Correlation Analysis}

As results revealed in Table 4, The correlation test clarifies that organizational culture as the independent variable significantly correlated to intellectual capital through $\mathrm{r}\left(0.554^{* *}\right)$. So, the correlation is significant at the 0.01 level (2-tailed) and the p-value (0.000), which is less than (0.05). Hence, the first hypothesis $\left(H_{1}\right)$ accepted, which stated that organizational culture has a positive relationship with intellectual capital at the level of $(0 \leq 0.05)$.

Table 4. Correlation between training and the organizational development

\begin{tabular}{llrr}
\hline & & Organizational Culture & Intellectual Capital \\
\hline Organizational & Correlation Coefficie & $\mathbf{1 . 0 0 0}$ & $\mathbf{0 . 5 5 4 * *}$ \\
Culture & Sig. (2-tailed) & $\cdot$ & $\mathbf{0 . 0 0 0}$ \\
Intellectual Capital & Correlation Coefficie & $\mathbf{0 . 5 5 4 * *}$ & $\mathbf{1 . 0 0 0}$ \\
& Sig. (2-tailed) & $\mathbf{0 . 0 0 0}$ &. \\
\hline
\end{tabular}

**. Correlation is significant at the 0.01 level (2-tailed).

*. Correlation is significant at the 0.05 level (2-tailed).

Table 5 demonstrates the outcomes of correlation test that organizational culture components namely; cultural values and norms, teamwork, participation, and culture of consistency all have a positive and significant correlation with intellectual capital, through $\mathrm{r}(0.494,0.521$, 0.327 , and 0.587$)$ respectively, at the 0.01 level (2-tailed) also the p-values $(0.000,0.000$, 0.000 , and 0.000$)$, which all less than alpha (0.05). While, the results determined that culture of consistency, the culture of teamwork, and respectively achieved the primary positive relationship with intellectual capital compared to the culture of participation. Therefore, hypotheses $\left(H_{1.1}, H_{1.2}, H_{1.3}\right.$, and $\left.H_{1.4}\right)$ all accepted.

Table 5. Correlation between training and the organizational development

\begin{tabular}{llc}
\hline Organizational Culture Components & Intellectual Capital \\
\hline Cultural Values and & Correlation Coefficie & $\mathbf{0 . 4 9 4}$ \\
Norms & Sig. (2-tailed) & $\mathbf{0 . 0 0 0}$ \\
Culture of & Correlation Coefficie & $\mathbf{0 . 5 2 1}$ \\
Teamwork & Sig. (2-tailed) & $\mathbf{0 . 0 0 0}$ \\
Culture of & Correlation Coefficie & $\mathbf{0 . 3 2 7 ^ { * * }}$ \\
Participation & Sig. (2-tailed) & $\mathbf{0 . 0 0 0}$ \\
Culture of & Correlation Coefficie & $\mathbf{0 . 5 8 7 ^ { * * }}$ \\
Consistency & Sig. (2-tailed) & $\mathbf{0 . 0 0 0}$ \\
\hline
\end{tabular}

**. Correlation is significant at the 0.01 level (2-tailed).

*. Correlation is significant at the 0.05 level (2-tailed).

c. Listwise $\mathrm{N}=82$. 


\subsection{Regression Analysis}

As demonstrated in Table 6, the multiple linear regression ran to the search and found the effect of organizational culture and its components in intellectual capital. The result through $\boldsymbol{R}$ square (0.301) approves the effect and correlation between the experimental and predicted values of the dependent variable intellectual capital. So, this result shows that organizational culture components such as cultural values and norms, teamwork, participation, the culture of consistency account for $30.1 \%$ of the intellectual capital at Salahaddin University colleges. The same Table 6 above displays F-test significance results of examining variance, the sum of squares, the degree of freedom (df), mean square, regression, and residual scores attained from the regression test. The mean square, which is the sum of squares divided by the degrees of freedom was (6.052). Besides, the F static that is regression mean square divided by the residual mean calculated was (34.399), and $\mathrm{df}$ is $(1,81)$. Consequently, the model is significance, although p-value less than alpha $(\mathrm{P} 0.000<0.05)$, the hypotheses $(\mathrm{H} 2$.) accepted.

Table 6. Model summary and $\mathrm{F}$ test significance

\begin{tabular}{lcccccc}
\hline Model & R & R Square & \multicolumn{2}{c}{ Adjusted R Square } & \multicolumn{2}{c}{$\begin{array}{c}\text { Std. The error of the } \\
\text { Estimate }\end{array}$} \\
\hline 1 & 0.554 & 0.301 & & 0.292 & 0.41946 & \\
\hline Model & & Sum of Squares & df & Mean Square & F & Sig. \\
\hline 1 & Regression & 6.052 & 1 & 6.052 & 34.399 & $.000^{\mathrm{b}}$ \\
& Residual & 14.076 & 80 & .176 & & \\
& Total & 20.128 & 81 & & & \\
\hline
\end{tabular}

a. Dependent Variable: Intellectual Capital.

b. Predictors: (Constant), Organizational Culture.

Table 7, illustrates the results of regression coefficients, clarifies significant effects of organizational culture and its components as cultural values and norms, the culture of teamwork, a culture of participation, the culture of consistency in the intellectual capital. These results found through the amounts of $(0.457,0.511,0.325$, and 0.548$)$, respectively, so the high effect of the culture of consistency and culture of teamwork. Moreover, Table 7 displays collinearity statistics through testing Tolerance and VIF. So, this test reveals if there is any autocorrelation between independent variables. Accordingly, a good regression model must free of autocorrelation. The tolerance and VIF values for each variable were; 1.000 and 1.000 , respectively, besides the same values for the rest components. While $\mathrm{VIF}<5$ and tolerance value $>0.1$, thus, collinearity does not exist. Additionally, the t-test (5.260) for organizational culture as the independent variable, it means that the effect significant and supports the results, accordingly, the $\mathrm{t}(4.600,5.310,3.127$, and 5.865) respectively, for all four components, were p $<0.05$ p-values less than alpha, the hypotheses $\left(\boldsymbol{H}_{2.1}, \boldsymbol{H}_{2.2}, \boldsymbol{H}_{2.3}\right.$, and $\boldsymbol{H}_{2.4}$ ) all accepted. 
Table 7. Regression coefficients

\begin{tabular}{|c|c|c|c|c|c|}
\hline \multirow[t]{2}{*}{ Model } & \multirow{2}{*}{$\begin{array}{c}\text { Standardized Coefficients } \\
\text { Beta }\end{array}$} & \multirow[t]{2}{*}{ T-test } & \multirow[t]{2}{*}{ P-value } & \multicolumn{2}{|c|}{ Collinearity Statistics } \\
\hline & & & & Tolerance & VIF \\
\hline (Constant) & - & 4.157 & .000 & & \\
\hline Organizational Culture & 0.507 & 5.260 & .000 & 1.000 & 1.000 \\
\hline Cultural Values and & 0.457 & 4.600 & .000 & 1.000 & 1.000 \\
\hline \multicolumn{6}{|l|}{ Norms } \\
\hline Culture of Teamwork & 0.511 & 5.310 & .000 & 1.000 & 1.000 \\
\hline Culture of Participation & 0.325 & 3.127 & .000 & 1.000 & 1.000 \\
\hline Culture of Consistency & 0.548 & 5.865 & .000 & 1.000 & 1.000 \\
\hline
\end{tabular}

a. Dependent Variable: Intellectual Capital.

\section{Conclusions and Recommendations}

This paper was purposed to examine the role of organizational culture on intellectual capital as a case study conducted at colleges of Salahaddin University-Erbil. As a result, this research found that organizational culture and it is components exercise a significant influence on intellectual capital according to the perspectives of college staff. Therefore, Salahaddin university and its colleges would professionally approach organizational culture, as well as mentioning the right atmosphere that can grow human capital capacities and boost innovative solutions. The research also found that the organizational culture through itis components, improving the level of staff's educational productivity and growing the invention. In addition to providing the academic staffs a vast space of freedom inside the colleges through intensifying the practical cultural values and norms, teamwork, participation, and culture of consistency, and offering all types of inspirations, providing opportunities, focusing on institutional cultures through teamwork, new ideas, and making a stimulating environment for academic staffs. The research found a significant positive correlation between organizational culture and intellectual capital. The results also determined that culture of consistency, the culture of teamwork, and respectively achieved the primary positive relationship with intellectual capital compared to the culture of participation. Additionally, the results of regression coefficients clarify significant effects of organizational culture and its components as cultural values and norms, the culture of teamwork, the culture of participation, culture of consistency in the intellectual capital.

For Salahaddin university and it is colleges to have influential organizational culture, institution's productive intellectual capital, and academic consistency, they would adopt a practical culture such as institutions values, norms, a culture of teamwork, participation, and culture of consistency that will support the succeeding of the intellectual capital. Therefore, it is critical to keep reasonable levels of organizational culture mainly through the institution's values that contributing to the college's vision, mission, and strategic objectives, besides matching the staff's ideals with organizational values to achieve the university objectives, as well as adopting the teamwork system as an effective strategy and do practical academic work through teamwork. Furthermore, it produces a suitable atmosphere that supports 
teamwork, in particular trying to involve experts from external parties to support existing teams. Salahaddin university and its colleges may encourage staff to put forward their creative ideas about all areas of the studies. Also, the need to implement the brainstorming method contributes to the exchange of thoughts and advantage from the opinions of others. The academic staff also cooperate and partner with the administration in solving work problems, thus, rely on information from the administrative levels to formulate the university strategy.

\section{References}

Chatzkel, J. (2002). Intellectual Capital. Printed and Bound in Great Britain.

Corcoles, Y. R. (2012). Toward improved information disclosure on intellectual capital in Spanish Universities. Global Journal of Human Social Science, 12(5), 1-7.

Daft, R. L. (2010). Organization: Theory and Design (7th ed.). Ohio, South-Western.

Dsvsnter, Van M. J. (2000). Developing Intellectual Capital, Chapter3. University of Pretoria, ETD.

Elias, S. (2006). The Influence of Organizational Culture on Human Resource Performance, Case Study of Algerian Aluminum Company. Unpublished Master's Thesis in Commercial Sciences, Mohammed Boudiaf University.

Farhaf, T. A., \& Abadi, H. D. (2006). The Interactive Relationship Between Knowledge Management and Intellectual Capital. Research presented to the first practical conference for the period from 19 to 18 April) College of Management and Economics, University of Karbala, Iraq.

Fernstrom, S. P., \& Roos, G. (2005). Intellectual capital Management Approach in ICS Ltd. Journal of Intellectual Capital, 6(4), 489-509. https://doi.org/10.1108/14691930510628780

Ghasemi, G., \& Naslmosavi, S. H. (2011) The Study of Intellectual Capital Measurement and It is Two Proposed New Models. lacsit press ipedr, 10(2), 430-434.

Khan, F. A., Khan, R. G., \& Khan, M. A. (2012). Impact of Intellectual Capital on Financial Performance of Banks in Pakistan: Corporate Restructuring and Its Effect on Employee Morale and Performance. International Journal of Business and Behavioral Sciences, 2(6), 22-30.

Mirkhan, K. M. A. (2002). The Relationship Between Cognitive Methods and Intellectual Capital and their Impact on Strategic Orientation. Unpublished Doctoral Thesis, University of Mustansiriya, Iraq.

Mustafa, H. A. (2016). Analysis of the Relationship of Intellectual Capital and Organizational Learning and its Impact on Achieving Business Entrepreneurship. Unpublished Master Thesis, in Business Administration, Salahaddin University- Erbil, Iraq.

Nordby J. R. (2005). The IC Rating model by Intellectual Capital Sweden. Journal of Intellectual Capital, 6(4), 570-587. https://doi.org/10.1108/14691930510628834 
Parnell, J., \& Crandall, W. (2001). Rethinking Participative Decision Making: A Refinement of the Propensity for Participative Decision-Making Scale. Personnel Review, 30(5), 523535. https://doi.org/10.1108/EUM0000000005937

Phatak, A. (2003). Intellectual Capital in Small Teams: Towards a Methodology for Capturing Intangible Assets. CSIRO Mathematical Information Sciences, 33(5), 3-81.

Rose, L. (2000). Valuing Intellectual Capital, Summary Report, Organizational Change Program for the cgiar Centers. Retrieved from http://www.iasj.net

Sánchez-Canizares, S. M., Munoz, M. A., \& Lopez-Guzman, T. (2007). Organizational Culture and Intellectual Capital: A New Model. Journal of Intellectual Capital, 8(3), 409-430. https://doi.org/10.1108/14691930710774849

Schein, E. H. (2010) Organizational Culture and Leadership (4th ed.). Jossey Bass, San Francisco.

Schreiner, M. (2005). The Influence of Organizational Culture on Alliance Competence and Performance: A Frame-Work Concept. Strategic Management Journal, 30, 1395-1419. https://doi.org/10.1002/smj.790

Shooshtri, K. J. (2016). Exploring the Effect of Organizational Culture on Job Satisfaction, Case of Namvaran Consulting Engineers, Managers Company. Unpublished Master Thesis, Business Administration, Luleå University of Technology.

Stephen, E. N., \& Stephen, E. A. (2016). Organizational Culture and its Impact on Employee Performance and Job Satisfaction: A Case Study of Niger Delta University. Amassoma. Higher Education of Social Science, 11(5), 36-45.

Stewart, T. (1999). Intellectual Capital: The New Wealth of Organizations. Doubleday-Currency, New York, NY.

Tarvonen, J. (2018). The Role of Corporate Culture in Company Performance Case: OK Perintä Oy. Business Economics, University of Applied Sciences.

Wali, A. I. (2007). The Relationship Between Organizational Knowledge and Intellectual Capital and its Influence in Determining the Strategic Choice. Unpublished Doctoral Thesis, Salahaddin University-Erbil, Iraq.

Zafar, H., Hafeez, M. H., \& Shariff, M. N. (2016). Relationship Between Market Orientation, Organizational Learning, Organizational Culture, and Organizational Performance: Mediating Impact of Innovation. South East Asia Journal of Contemporary Business, Economics and Law, 9(2), 40-56.

Zeyada, M. (2018). Organizational Culture and its Impact on Organizational Citizenship Behavior. International Journal of Academic Research in Business and Social Sciences, 8(3), 418-429. https://doi.org/10.6007/IJARBSS/v8-i3/3939 


\section{Appendix}

Appendix 1. Questionnaire Form

Dear Respondent

This questionnaire is a part of the research paper to measure "The role of organizational culture in intellectual capital: A case study of Salahuddin University-Erbil." I will be pleased to participate in the survey by answering its questions that discussing to respondent performs and knowledge as it would have a substantial consequence in outputting this research paper at the required level.

\section{Thanks in advance}

\section{First: General Information}

Gender: Male ( ) Female ( ).

Age: Less than 30 years ( ) 30 and less than 40 years ( ) 40 and less than 50 years ( ) 50 and above.

Academic Degree: PhD ( ) Master ( ).

Scientific Title: Professor ( ), Asst. Professor ( ), Lecturer ( ), Asst. Lecturer

Experience in Academic Profession: Less than 10 years ( ), 10 and less than 20 ( ), 20 and less than 30 years ( ) 30 and years and above ( ).

Second: The Scale of Organizational Culture

\begin{tabular}{|c|c|c|c|c|c|c|}
\hline \multirow[t]{2}{*}{$Q$} & \multirow[t]{2}{*}{ Statements } & 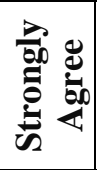 & 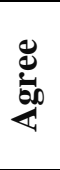 & 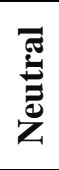 & 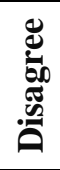 & 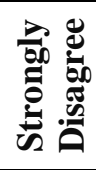 \\
\hline & & 5 & 4 & 3 & 2 & 1 \\
\hline \multicolumn{7}{|c|}{ First Dimension: Cultural Values and Norms } \\
\hline 1 & $\begin{array}{l}\text { The college chases to match the staffs' values with } \\
\text { organizational values to achieve the university objectives. }\end{array}$ & & & & & \\
\hline 2 & $\begin{array}{l}\text { The college departments have a transparent and public } \\
\text { document expressing their values. }\end{array}$ & & & & & \\
\hline 3 & $\begin{array}{l}\text { The rules adopted by the academic departments apply to all } \\
\text { staff without exception. }\end{array}$ & & & & & \\
\hline 4 & $\begin{array}{l}\text { The college administration may ignore some values and } \\
\text { principles for students and public benefits. }\end{array}$ & & & & & \\
\hline 5 & $\begin{array}{l}\text { The values contribute to the college's vision, mission, and } \\
\text { strategic objectives. }\end{array}$ & & & & & \\
\hline \multicolumn{7}{|c|}{ Second Dimension: Culture of Teamwork } \\
\hline 6 & $\begin{array}{l}\text { The college administration adopted the teamwork system as an } \\
\text { effective strategy. }\end{array}$ & & & & & \\
\hline 7 & $\begin{array}{l}\text { The college's most academic and practical work is done } \\
\text { through teamwork. }\end{array}$ & & & & & \\
\hline 8 & $\begin{array}{l}\text { The college administration produces a suitable atmosphere that } \\
\text { supports teamwork. }\end{array}$ & & & & & \\
\hline 9 & The college administration is trying to involve experts from & & & & & \\
\hline
\end{tabular}




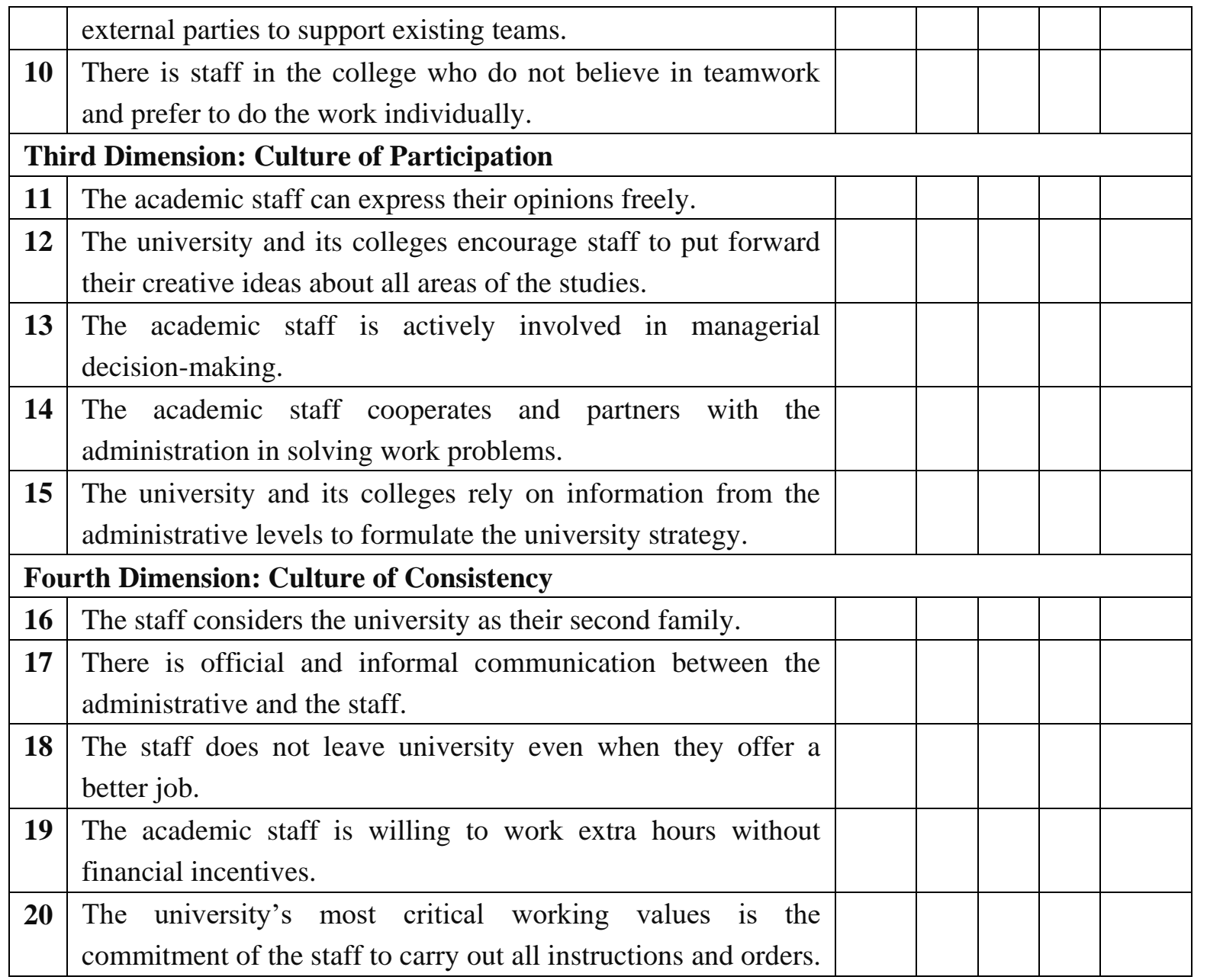

Third: The Scale of Intellectual Capital

\begin{tabular}{|c|c|c|c|c|c|c|}
\hline \multirow[t]{2}{*}{$Q$} & \multirow[t]{2}{*}{ Statements } & 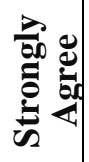 & 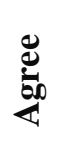 & 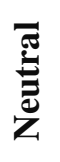 & 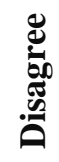 & 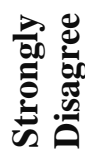 \\
\hline & & 5 & 4 & 3 & 2 & 1 \\
\hline \multicolumn{7}{|c|}{ First Dimension: Human Capital } \\
\hline 1 & The college has highly skilled and experienced staff. & & & & & \\
\hline 2 & $\begin{array}{l}\text { The college pursues to adopt administrative empowerment and } \\
\text { methods of management based on trust to maintain the best staff. }\end{array}$ & & & & & \\
\hline 3 & $\begin{array}{l}\text { The college feels that they can manage themselves at the required } \\
\text { level and are responsible for the performance of their academic } \\
\text { effort. }\end{array}$ & & & & & \\
\hline 4 & $\begin{array}{l}\text { The college administration encourages a competitive spirit among } \\
\text { it is academic staff. }\end{array}$ & & & & & \\
\hline 5 & $\begin{array}{l}\text { The college is working to attract human resources who possess } \\
\text { sufficient skills and experience in the field of planning, } \\
\text { organization, and control to occupy critical administrative } \\
\text { positions. }\end{array}$ & & & & & \\
\hline
\end{tabular}




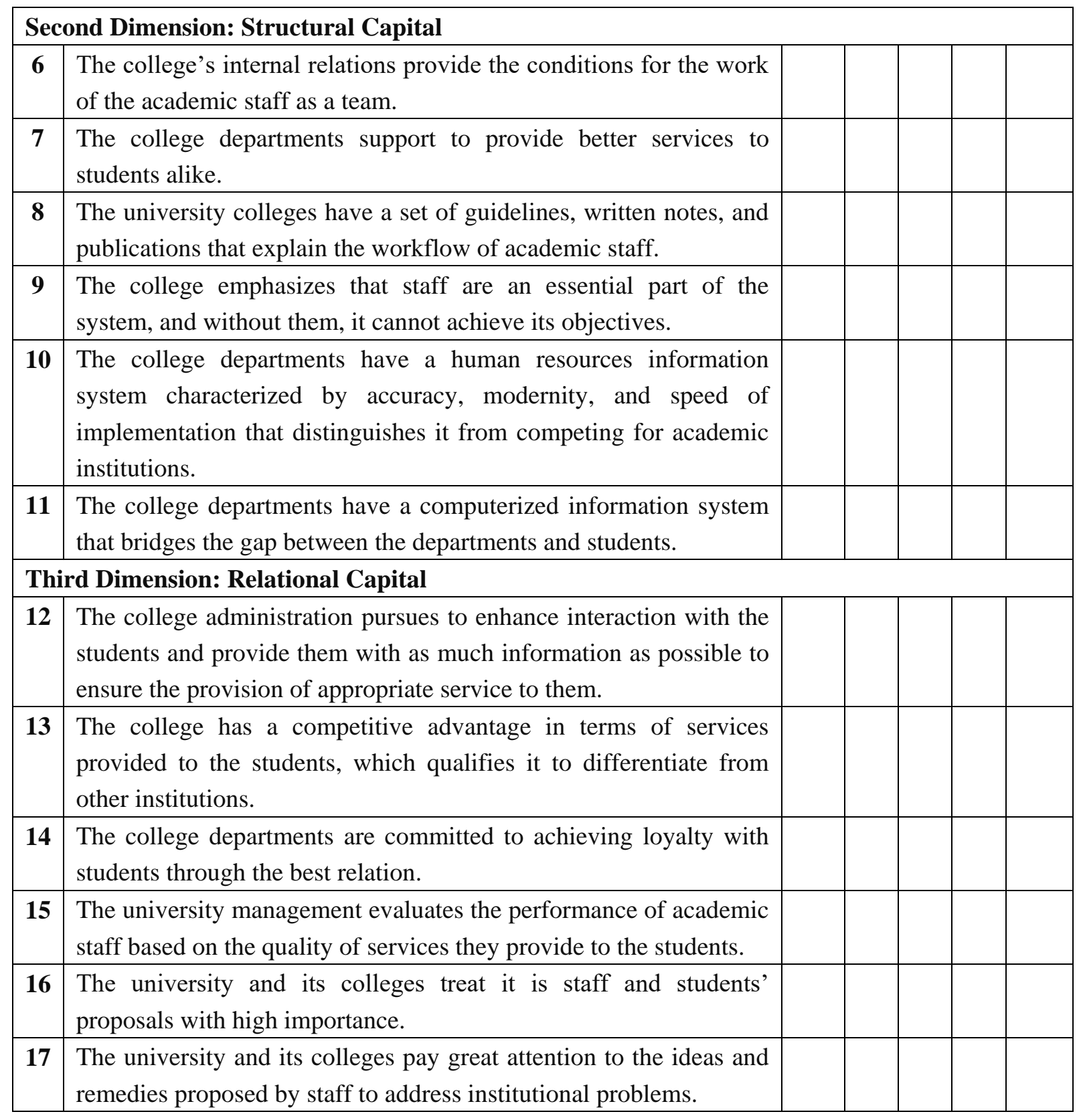

\section{Copyright Disclaimer}

Copyright for this article is retained by the author(s), with first publication rights granted to the journal.

This is an open-access article distributed under the terms and conditions of the Creative Commons Attribution license (http://creativecommons.org/licenses/by/3.0/). 